\title{
СИНТЕЗ І АНАЛІЗ ІНФОРМАЦИЙНО-УПРАВЛЯЮЧИХ СИСТЕМ СИНХРОНІЗАЦІЇ ЗАСОБІВ ТЕЛЕКОМУНІКАЦІЙ
}

Анотація: В роботі представлено результати синтезу та аналізу інформаційно-управляючих систем блоків синхронізації засобів телекомунікацій на основі поліфазних і багатофазних фільтруючих пристроїв.

Ключові слова: інтерполяція, синхронізація, управління, фільтр, завадостійкість.

\section{Постановка проблеми}

Розвиток телекомунікаційних технологій у всьому світі висуває особливі вимоги до показників якості інформаційно-управляючих систем пристроїв синхронізації [1-5]. Щоб забезпечити такі вимоги, необхідна більш гнучка архітектура таких пристроїв обробки сигналів. Тоді в умовах використання в каналах передачі інформації сигналів у вигляді складних сигнально-кодових конструкцій, виникла б можливість підвищення ефективності обробки сигналів в засобах телекомунікацій, особливо в частині, що стосується забезпечення їх завадостійкості в умовах завад і шумів [1-6].

Подання інформації в цифровій формі забезпечує високу завадостійкість при передачі по різних каналах, можливість ефективного використання пропускної здатності каналів, стабільність параметрів передачі та гнучкість при побудові цифрових засобів телекомунікацій $[1,2]$. Одним з основних процесів, який впливає на загальну завадостійкість прийому цифрових кодованих сигналів, є процес синхронізації демодулятора квадратурних сигналів. Правильна демодуляція квадратурних сигналів можлива тільки когерентним способом, для чого необхідно максимально точно виконати умову синхронізації по фазі місцевого опорного генератора приймального пристрою і носійної частоти. У разі цифрового телекомунікаційного каналу немає можливості безпосередньо синхронізувати передавач і приймач, тому копію носійної в приймальному пристрої необхідно відновлювати з сигналу. У більшості досліджень основний акцент ставиться на використанні інформаційно-управляючих пристроїв синхронізації побудованих на системах фазового автоматичного підстроювання (ФАП), а теорія і практика використання модифікованих

\footnotetext{
${ }^{\odot}$ Ю. М. Бойко
} 
схем синхронізації блоків обробки сигналів на інтерполяційних інформаційно-управляючих схемах з передискретизацією недосконала і вимагає проведення окремих досліджень. На сьогодні актуальним завданням є використання модифікованих способів синхронізації на основі врахування впливу завад сусідніх символів на фазовий критерій тракту, зокрема, використання модифікованої схеми синхронізації, в отриманні формалізованого представлення опису схем синхронізації на основі багатофазних конструкцій з використанням банку фільтрів, що дозволяє покращити характеристики цифрових телекомунікаційних каналів. Дослідженню і моделюванню даних способів присвячена наукова стаття.

\section{Аналіз останніх досліджень і публікацій}

Обробка сигналів у цифрових системах зв'язку неодмінно пов'язана 3 перетворенням їх у послідовність відліків, прив'язаних до конкретних моментів часу, тобто з проведенням дискретизації сигналів за часом. Для отримання значень дискретизованого сигналу використовуються головним чином аналого-цифрові перетворювачі з рівномірною дискретизацією. Однак, при вирішенні задач побудови модифікованих схем обробки сигналів, існує можливість використання алгоритмів нерівномірної дискретизації сигналів [6-10].

При дискретизації, в контексті цифрової обробки сигналів, звичайно передбачається, що вибірка вважається детермінованою і періодичною. Перетворення частоти дискретизації $F=1 / T$ представляє собою зміну частоти дискретизації дискретного сигналу. Коли нова частота дискретизації вище дійсної так, що $F />F$ і $T /<T$, то в цілому цей процес називається інтерполяцією, суть якої полягає в додаванні нулів кількістю $\left(F^{/} / F\right)$-1 між двома сусідніми відліками. В результаті утворюється нова послідовність 3 частотою дискретизації $F^{\prime}$, для якої застосовується інтерполяційний фільтр. Для підвищення ефективності синхронізації пропонується метод перетворення частоти дискретизації за допомогою поліфазних фрільтрів. Поліфазний фільтр представляє собою набір невеликих фільтрів, що працюють паралельно, кожен з яких обробляє тільки підмножину відліків сигналу. При цьому формується нова послідовність і не виконуються зайві обчислення, тому що для кожного відліку необхідно обчислити вихідний сигнал тільки одного з цих фільтрів. В даний час для відновлення сигналів з нерівномірною дискретизацією досліджуються різні методи перетворення частоти дискретизації, які розраховані на незначні коливання відхилень інтервалу дискретизації [1]. Реконструювати такий сигнал можна тільки 
за допомогою цифрової обробки сигналів, вважаючи коливання висоти тону (детонацію) як нерівномірні відліки сигналу в часі. У зв'язку з цим, дуже важливо знайти рішення задачі побудови пристрою синхронізації модифікованого типу i можливість застосування структури Фарроу для безперервного регулювання перетворення частоти дискретизації, з метою відновлення нерівномірних відліків оцифрованого сигналу, і подальшого їі застосування в цифровій обробці сигналів в інформаційно-управляючих системах засобів телекомунікацій для підвищення їх завадостійкості.

Основне рівняння інтерполяції дискретного сигналу записується у вигляді $[8,9]:$

$$
\begin{gathered}
y\left(l T_{i}\right)=y\left[\left(n_{l}+\mu_{l}\right) T_{i n}\right]= \\
=\sum_{i=I_{1}}^{I_{2}} x\left[\left(n_{l}-i\right) T_{i n}\right] h_{I}\left[\left(i+\mu_{l}\right) T_{i n}\right],
\end{gathered}
$$

де $\{x(n)\}$ - послідовність відліків сигналу з інтервалом $T_{i n} ; h_{I}(t)$ - імпульсна характеристика інтерполяційного нерекурсивного фільтру; $i$ - індекс фільтру; $n_{l}$ - вихідна координата, що визначає $I=I_{2}-I_{1}+1$ відліків сигналу для використання $l$-м інтерполятором; $\mu_{l}$ - дробовий інтервал дискретизації який визначає коефіцієнти фільтра $l$-го інтерполянта.

Імпульсна характеристика інтерполяційного фільтру виражається в кожному інтервалі за допомогою полінома ступеня $M$ :

$$
h_{I}(t)=h_{i}\left[\left(i+\mu_{l}\right) T_{i n}\right]=\sum_{m=0}^{M} c_{m}(i) \mu_{l}^{m} .
$$

Число поліноміальних коефіцієнтів $c_{m}(i)$ є постійним, не залежить від $\mu_{1}$, і визначається виключно імпульсною характеристикою інтерполяційного фільтру $h_{I}(t)$. Після математичних перетворень отримаємо вирази інтерполянтів:

$$
y(l)=\sum_{i=I_{1}}^{I_{2}} x\left(n_{l}-i\right) \sum_{m=0}^{M} c_{m}(i) \mu_{l}^{m} \sum_{i=I_{1}}^{I_{2}} c_{m}(i) x\left(n_{l}-i\right)=\sum_{m=0}^{M} \mu_{l}^{m} v(m),
$$

де $v(m)$ - відліки сигналу з виходу $M+1$ інтерполяційних нерекурсивних фільтрів з відповідними коефіцієнтами імпульсними характеристиками $c_{m}\left(I_{1}\right), c_{m}\left(I_{1}+1\right) \ldots c_{m}\left(I_{2}\right)$.

Тоді передавальна функція такого не рекурсивного фільтра буде мати вигляд:

$$
C_{m}(z)=\sum_{i=I_{1}}^{I_{2}} c_{m}(i) z^{-i}
$$


Таким чином, вираз (4) є поліномом від параметра $\mu_{l}^{m}$, який буде єдиним змінним параметром структури. До складу такої структури входить $M+1$ нерекурсивних фільтрів з постійними коефіцієнтами, включеними паралельно, результати яких множаться на дробовий інтервал дискретизації.

Використовуємо поліноми Лагранжа для побудови фільтрів Фарроу. Представимо безперервний сигнал як суму добутків відліків на поліном Лагранжа:

$$
y_{a}(t)=\sum_{n=0}^{M-1} y(l) \cdot X_{I}^{M-1}\left(\mu_{l}\right),
$$

де $M$ - ступінь полінома, поліном дорівнюе одиниці в момент дискретизації $l$-го відліку і дорівнює нулю в інші моменти дискретизації.

Використовуємо формулу (4) і представимо передавальну функцію поліфазного фільтра в наступному вигляді:

$$
G_{I}(z)=C_{0}(z)+C_{1}(z) \cdot \mu_{l}+C_{2}(z) \cdot \mu_{l}^{2}+C_{3}(z) \cdot \mu_{l}^{3} .
$$

Отримано такий вид коефіцієнтів поліному (6).

$$
\begin{gathered}
C_{0}(z)=z^{-2}, C_{1}(z)=\frac{1}{2}\left(z^{-3}-z^{-1}\right)-C_{3}(z), \\
C_{2}(z)=z^{-3}-z^{-2}-C_{1}(z)-C_{3}(z), \\
C_{3}(z)=\frac{1}{6}\left(z^{-3}-z^{0}\right)+\frac{1}{2}\left(z^{-1}-z^{-2}\right) .
\end{gathered}
$$

Модифіковані схеми поліфазних фільтрів Фарроу представлені на рис. 1а, б.

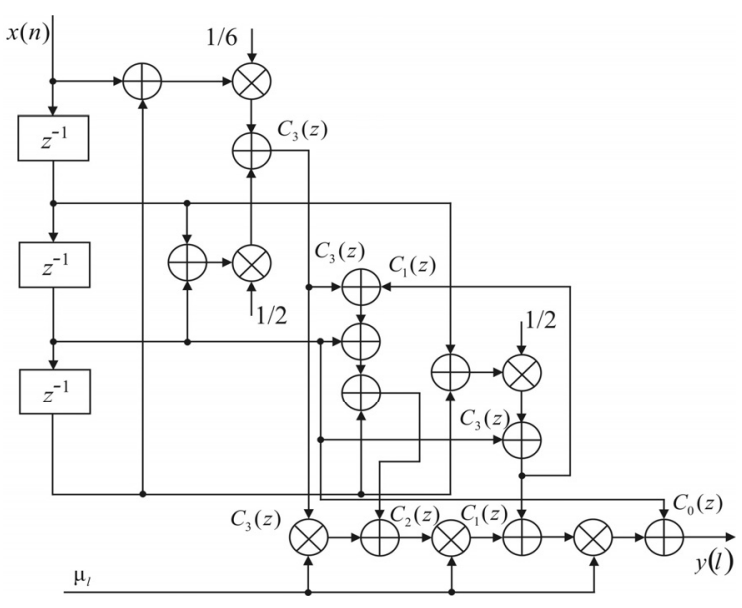

a

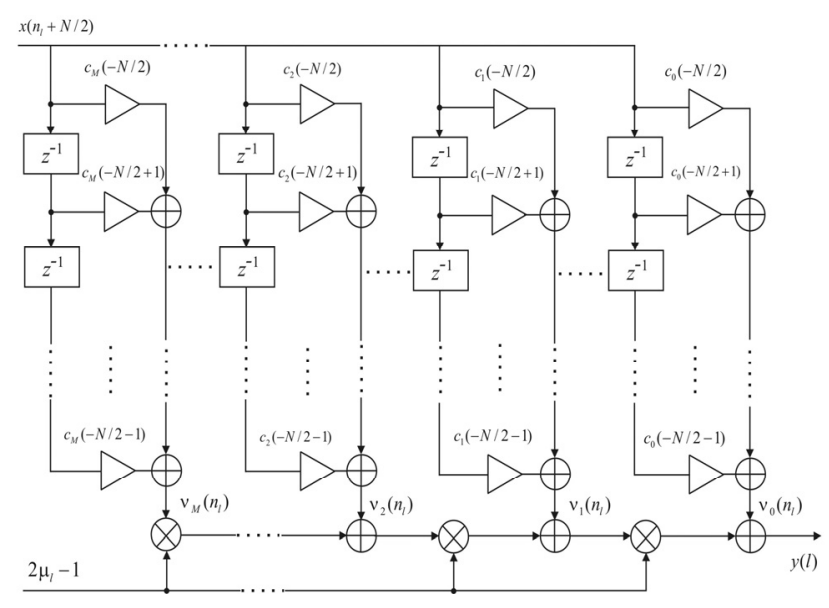

6

Рис. 1. Модифіковані схеми поліфазного фільтра Фарроу: а - варіант 1; б - варіант 2

Використовуємо аналітичний вираз (2) для імпульсної характеристики інтерполяційного фільтра і опишемо ще один підхід до модифікації 
структури інтерполятора Фарроу для системи синхронізації. Замість параметра $\mu_{l}$ в (2) використовуємо конструкцію типу $\left(2 \mu_{l}-1\right)$ для утворення дробового інтервалу. Представимо імпульсну характеристику фільтра наступним чином:

$$
h_{i}\left[\left(n+\mu_{l}\right) T_{i n}\right]=\sum_{m=0}^{M} c_{m}(n)\left(2 \mu_{l}-1\right)^{m}
$$

де $n=-N / 2,-N / 2+1, \ldots . ., N / 2-1$.

Якщо $\mu_{l}$ буде змінюватись від 0 до 1 , тоді $h_{i}(t)$ імпульсна характеристика буде приймати на кожному інтервалі $\left[k T_{i n},(k+1) T_{i n}\right]$ для $k=-N / 2, \ldots, N / 2-1$ наступну конструкцію:

$$
h_{i}(t)=\sum_{m=0}^{M} c_{m}(k)\left(\frac{2\left(t-k T_{i n}\right)-1}{T_{i n}}\right)^{m},
$$

Властивості симетрії $h_{i}(-t)=h_{i}(t)$ можна уявити так $c_{m}(n)=$ $=(-1)^{m} c_{m}(-n-1)$, для $m=0,1, \ldots, M$ і $n=0,1, \ldots, N / 2-1$.

Для дослідження запропонованих рішень проведемо розробку імітаційної схеми телекомунікаційної системи передачі даних. Порівняння результатів дослідження запропонованих рішень при побудові інформаційно-управляючих систем пристрою синхронізації будемо проводити на основі аналізу багатофазної системи управління.

\section{Мета і завдання дослідження}

Метою дослідження є розробка математичних моделей формалізованого опису процесу синтезу модифікованих інформаційно-управляючих пристроїв синхронізації, розробка апарату багатофазної інтерполяції з розширенням технічної інтерпретації багатофазних узгоджених фільтрів пристроїв синхронізації. Необхідно провести побудову математичної моделі шляхом формалізації рішення рівняння багатофазної інтерполяційної системи, визначити залежності оцінки від фазової помилки і нормованої часової помилки при різних значеннях дробового інтервалу і багатофазної конструкції банку узгоджених фільтрів в приймачах маніпульованих сигналів телекомунікаційних систем передачі інформації.

Для досягнення поставленої мети необхідно було вирішити такі завдання:

- експериментально дослідити вплив значень дробового інтервалу інтерполяції інформаційно-управляючої системи на величину помилки пристрою синхронізації; 
- використовуючи метод констеляційних діаграм, око-діаграм, побудови кривої завадостійкості - провести оцінку помилки за констеляційною діаграмою, оцінити джитер за розкривом око-діаграми і зміну завадостійкості при фіксованому значенні ймовірності бітової помилки.

\section{Основна частина}

Для побудови пристрою синхронізації використовуємо набір фільтрів які дозволяють провести багатофазну реалізацію узгодженого фільтра при інтерполяції замість окремого поліноміального інтерполяційного фільтра. Таким чином, інтерполяція і узгоджена фільтрація будуть згорнуті в одну операцію. Поліфазний банк фільтрів також дозволяє легко управляти фазою з метою узгодження швидкостей $1 / T_{\text {in }} \mathrm{i}$ $1 / T_{i}$. На рис.2 представлена функціональна схема інформаційноуправляючої системи на основі інтерполяційного пристрою системи синхронізації.

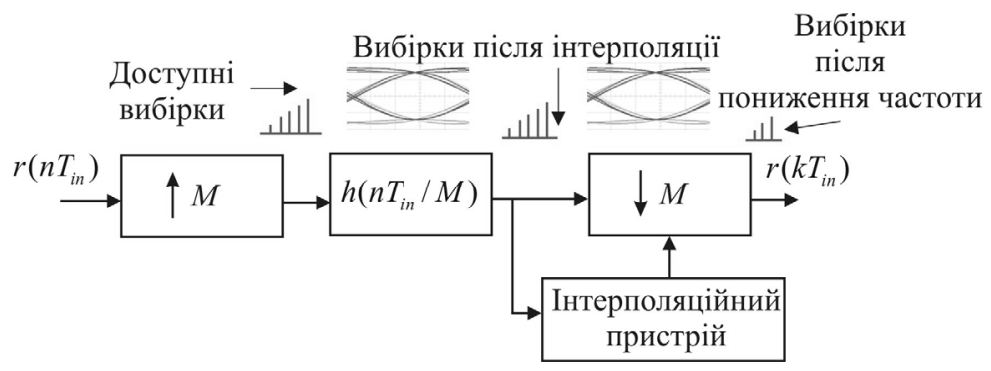

Рис. 2. Функціональна схема інформаційно-управляючої системи з інтерполяційним пристроєм

Процес роботи такої схеми можна описати таким чином: послідовність відліків вхідного сигналу $r\left(n T_{i n}\right)$ коригується шляхом зміни частоти дискретизації ( $M$ і $N$ ), а фаза прийнятого комплексного сигналу основної смуги частот відновлюється за $N$ вибірок на символ. Дискретизація послідовності відліків підвищується 3 коефіцієнтом $M$, після чого утворюється нова послідовність відліків, яку позначимо $r\left(n T_{i n} / M\right)$.

Послідовність, яка утворюється на виході узгодженого фільтра, містить $2 L$ символів. Система управління процесом синхронізацією вибирає $N$ відліків протягом кожного символьного періоду, тоді вихід задається рівнянням:

$$
y\left(n \frac{T_{i n}}{M}\right)=\sum_{l=-M N L}^{M N L} r\left((n-l) \frac{T_{i n}}{M}\right) h\left(l \frac{T_{i n}}{M}\right),
$$


після чого вихідний сигнал зменшується по частоті дискретизації для отримання $N$ вибірок на символ, де один із зразків є найближчим до $y\left(n T_{i n}+\tau\right)$ з можливим роз різненням. У випадку багатофазного розкладання потрібні не всі відліки які визначаються з (9):

$$
r\left(n \frac{T_{i n}}{M}\right)=\left\{\begin{array}{l}
r\left(n T_{i n}\right), \quad n=0, \pm M, \pm 2 M, . . \\
0 \text { iнu }
\end{array},\right.
$$

де кожний $M$-й відлік відрізняється від нуля для КІХ-фільтра (трансверсального).

На момент часу який відповідає високій частоті дискретизації, значення відмінні від нуля збігаються 3 коефіцієнтами фільтра: $h\left(-2 M T_{i n}\right), h\left(-M T_{i n}\right), h(0), h\left(M T_{i n}\right), h\left(2 M T_{i n}\right), \ldots$

Результат фільтрації представимо наступним чином:

$$
\sum_{i=-N L}^{N L} r\left((n-i) T_{i n}\right) h\left(i T_{i n}\right)=y\left(n T_{i n}\right) .
$$

В наступні моменти часу не нульові значення $r\left(n T_{i n} / M\right)$ збігаються з коефіцієнтами фільтра:

$$
h\left(-2 M T_{i n}+1\right), h\left(-M T_{i n}+1\right), h(1), h\left(M T_{\text {in }}+1\right), h\left(2 M T_{i n}+1\right), \ldots
$$

Таким чином, вихідні відліки фільтра можна аналітично представити таким чином:

$$
\sum_{i=-N L}^{N L} r\left((n-i) T_{i n}\right) h\left(\left(i+\frac{1}{M}\right) T_{i n}\right)=y\left(\left(n-\frac{1}{M}\right) T_{i n}\right)
$$

Для $m$-го моменту часу, відмінні від нуля значення $r\left(n T_{\text {in }} / M\right)$ збігаються з коефіцієнтами фільтра:

$$
h\left(-2 M T_{i n}+m\right), h\left(-M T_{i n}+m\right), h(m), h\left(M T_{i n}+m\right), h\left(2 M T_{i n}+m\right), \ldots
$$

Тоді вихідні відліки можна аналітично представити:

$$
\sum_{i=-N L}^{N L} r\left((n-i) T_{i n}\right) h\left(\left(i+\frac{m}{M}\right) T_{i n}\right)=y\left(\left(n-\frac{m}{M}\right) T_{i n}\right) .
$$

Графічно (13) можна уявити рис.3, де представлений паралельний банк з $M$ фільтрів які працюють при частоті дискретизації $1 / T_{\text {in }}$. Кожний фільтр з банку фільтрів працює з пониженням частоти дискретизації відліків на виході узгодженого фільтра. Імпульсну характеристику для $h_{m}\left(n T_{i n}\right)$ представимо наступним чином: 


$$
h_{m}\left(n T_{i n}\right)=h\left(n T_{i n}+\frac{m}{M} T_{i n}\right) .
$$

Еталонні відліки даних в схемі, утворюються одночасно на всіх фільтрах з реалізованого банку фільтрів. Необхідний фазовий зсув на виході вибирається при підключенні виходу до відповідного фільтру в банку фільтрів.

Безпосередня реалізація фільтруючої системи на основі банку фільтрів буде характеризуватися вимогами до їх паралельної роботи. На практиці, досить реалізувати одноланковий фільтр з набором вагових еквівалентів, які вибираються з пам'яті за допомогою покажчика під контролем системи управління на основі фазового автопідстроювання частоти.

Розглянемо можливі схемотехнічні особливості реалізації детекторів фазової помилки для інформаційно-управляючих пристроїв блоків синхронізації з використанням багатофазного банку фільтрів. На рис. 4 представлена схема використання багатофазної конструкції на основі банку фільтрів для детектора з вікном на "випередження-затримку" [7].

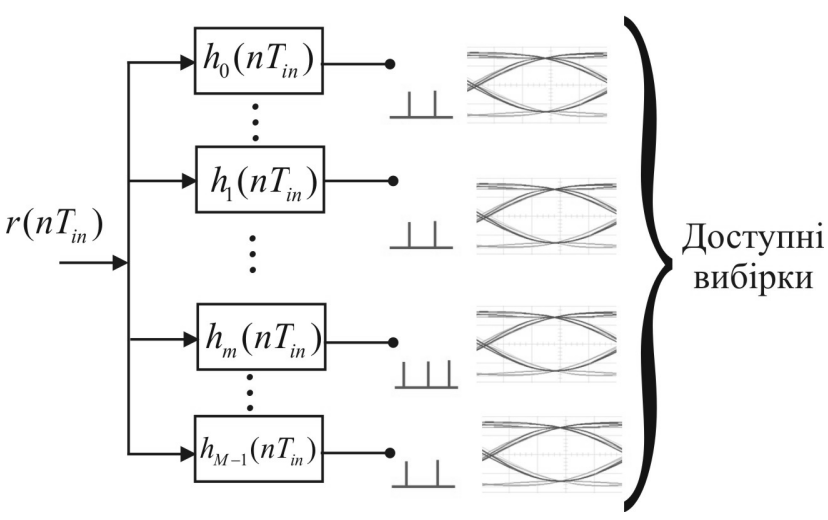

Рис. 3. Схема багатофазної конструкції банку узгоджених фільтрів

У схемі виходи багатофазних фільтрів безпосередньо використовуються для формування фазової помилки, яку визначимо як $\Delta \tau / T_{\text {in }}=1 / M N$. В схемі використовуються три виходи з багатофазного банку фільтрів, два для обчислення помилки пристрою синхронізації з вікном на "випередження-затримку" і один вихід для отримання результату узгодженої фільтрації. 


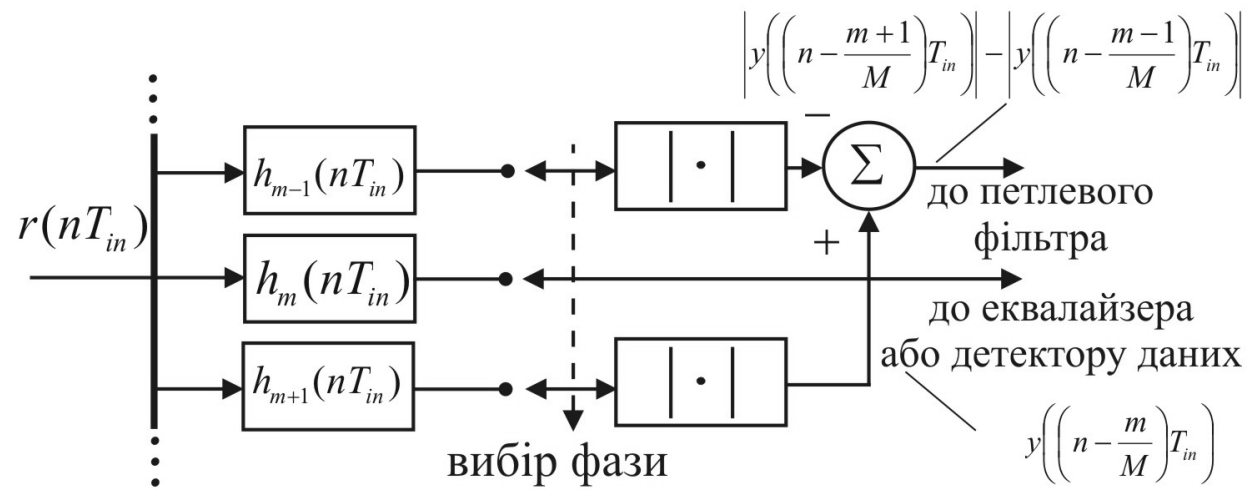

Рис. 4. Схема багатофазної конструкції для детектора фазової помилки пристроїв синхронізації з вікном на "випередження-затримку"

На рис.5 представлена схема багатофазної конструкції для детектора максимального правдоподібності пристроїв синхронізації (використовується два фільтри для обчислення похідної):

$$
\begin{gathered}
\dot{h}_{m}\left(n T_{i n}\right)=h_{m+1}\left(n T_{i n}\right)-h_{m-1}\left(n T_{i n}\right) \text { де } m=1,2, \ldots, M-2 ; \\
\dot{h}_{0}\left(n T_{i n}\right)=h_{1}\left(n T_{i n}\right)-h_{M-1}\left(n T_{i n}\right) ; \dot{h}_{M-1}\left(n T_{i n}\right)=h_{M-2}\left(n T_{i n}\right)-h_{0}\left(n T_{i n}\right) .
\end{gathered}
$$

Розглянемо особливості архітектури кола управління пристрою синхронізації з використанням поліфазних фільтруючих систем. Архітектура містить чотири основні складові: поліфазний і узгоджений фільтр, детектор часової помилки, петлевий фільтр і контролер. Багатофазний узгоджений фільтр тактується відліками, які надходять через кожні $T_{i n}$ секунд. Детектор помилки синхронізації пов'язаний з узгодженим фільтром, $з$ виходів якого подаються відліки на поліфазний банк фільтрів кожні $T / N$ секунд, і виводить повідомлення про помилку синхронізації кожні $T$ секунд.

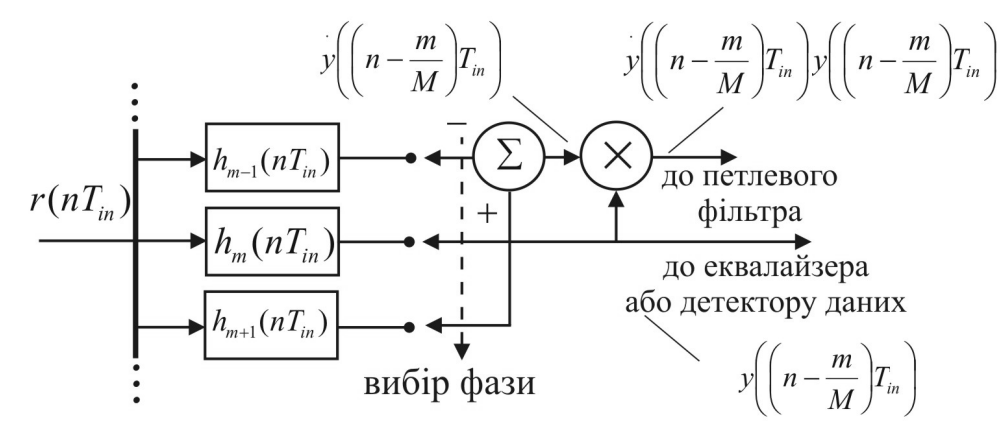

Рис. 5. Схема багатофазної конструкції для детектору максимальної правдоподібності пристроїв синхронізації (використовується два фільтра для обчислення похідної) 
Детектор помилок синхронізації використовується для приведення в дію фільтра зворотного зв'язку і контролера контуру $[12,13]$. Можна виділити наступні рішення для реалізації кола управління зворот-

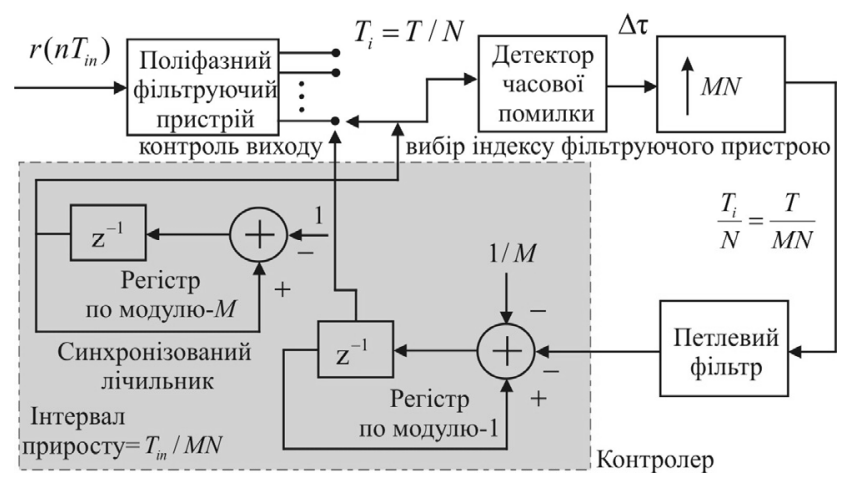

Рис. 6. Схема управління петлі регулювання пристрою синхронізації який працює по $M N$ вибіркам/символ ного зв'язку $M$-подібним багатофазним узгодженим фільтром: фільтр контуру і контролер управляються $M N$ вибірками/символ; $N$ - вибірками/символ або однією вибіркою/символ. Конструкції описаних вище пристроїв синхронізації представимо на рис. 6 і рис. 7 .

В схемі на рис. 6 використано два лічильника синхронізації з зразковими вибірками. Один лічильник по модулю $M$, забезпечує вибір індексу фільтруючого пристрою, а нижній лічильник по модулю - 1 .

На схемі поданої на рис.7, представлено коло управління петлі регулювання пристрою синхронізації, яке працюе за $N$ вибіркам/символ. Контроль процесу інтерполяції проводиться на основі лічильника по модулю 1, який функціонує як генератор керований кодом (NCO). Зміст регістру переповнення використовується для розрахунку індексу багатофазної фільтрації. Новий інтерполянт утворений багатофазним узгодженим фільтром за допомогою $N$ вхідних вибірок. У випадку, коли регістр переповнений, інтервал проведення інтерполяції зміщується в кінець багатофазного фільтра, цей процес здійснюється під управлінням блоку "контроль стану".

В схемі на рис. 7 об'єднані узгоджений фільтр i інтерполятор в одному багатофазному фільтрі. В цьому випадку, коло управляється за допомогою $N$ вибірок/символ і вимагає тільки одного лічильника по модулю 1. Лічильник обнулюється 3 періодом $T / N$ для $N$ часових

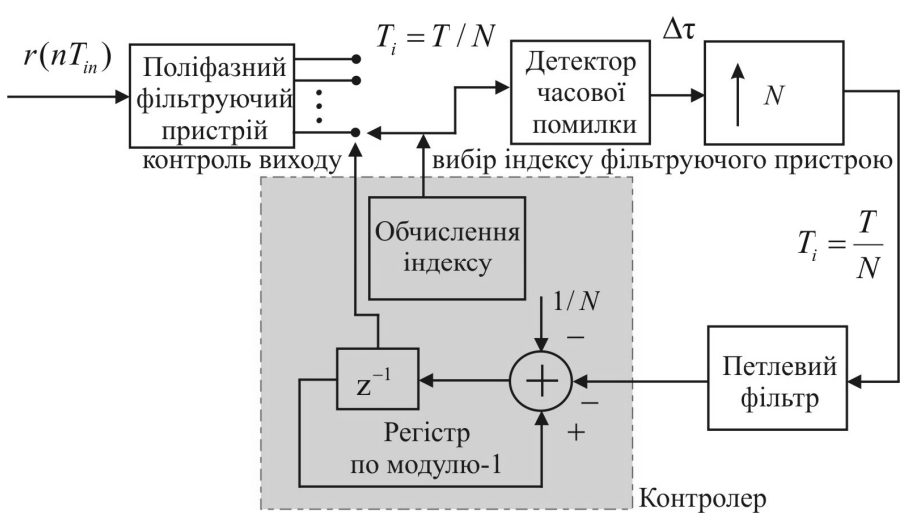

Рис. 7. Схема управління петлі регулювання пристрою синхронізації працює за $N$ вибірках/символ 
вибірок на символ. Інший лічильник забезпечує управління багатофазним узгодженим фільтром. Відповідний індекс багатофазного фільтруючого пристрою обчислюється аналогічно, шляхом квантування необхідним інтерполяційним інтервалом $\mu$, до найближчого числа, кратного $1 / M$.

Для дослідження запропонованих рішень проведемо розробку імітаційної схеми системи передачі даних 3 інформаційно-управляючою системою на основі модифікованої поліфазної конструкції рис. 8. Вибірка сигналу здійснюються за допомогою фіксованого тактового сигналу дискретизації, таким чином, відбір відліків не синхронізований з прийнятим сигналом. В цьому випадку легко змінити частоту дискретизації, причому частота дискретизації не повинна бути кратна частоті символів. Крім того немає необхідності в застосуванні системи фазового автоматичного підстроювання (ФАПЧ) [7].

На рис.9 представлена розроблена імітаційна схема. В схемі сигнал утворюється в підсистемі "схема формування сигналу" до складу якої входить підсистема "модулятор". В схемі вихідний сигнал після скремблюванння потрапляє на кодер Грея, далі відбувається диференціальне кодування, екстраполяція, передискретизація («Upsample») i обмеження сигналу по спектру фільтруючим пристроєм («FIR Filter»). Далі в схемі на рис. 9 вихідний сигнал потрапляе на підсистему поліфазний інтерполятор «Polyphase interpolator» і в канал передачі інформації. Фазова помилка для проведення експерименту задається блоком «Phase offset».

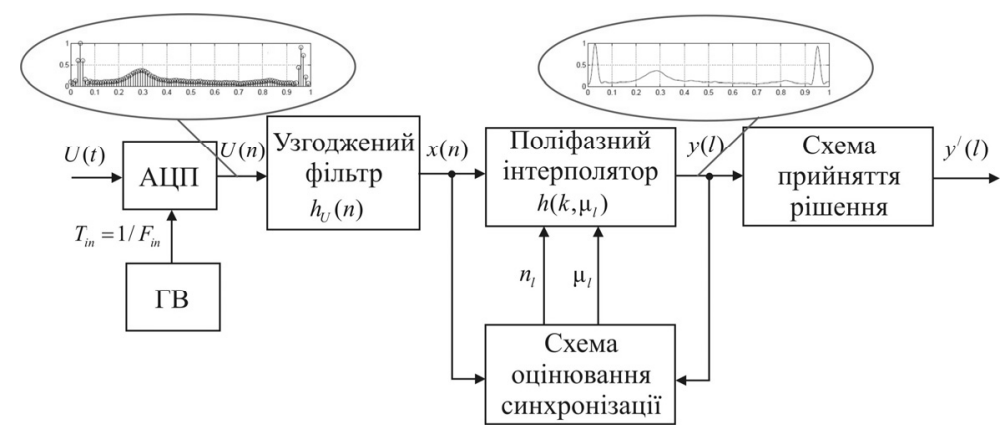

Рис. 8. Схема цифрового приймача з інформаційно-управляючою системою на основі поліфазного інтерполятора: ГО - генератор вибірок (тактів)

Приймання переданої інформації виконується за допомогою пристрою обробки сигналів, основа якого інформаційно-управляюча схема синхронізації з поліфазним інтерполятором. До складу схеми, відповідно до рис. 8, входить: узгоджений фільтр «Matched filter» (цифровий 
КIX - фільтр нижніх частот, типу піднятий косинус, порядок - 32 , тип вікна Bохсаг), поліфазний інтерполятор

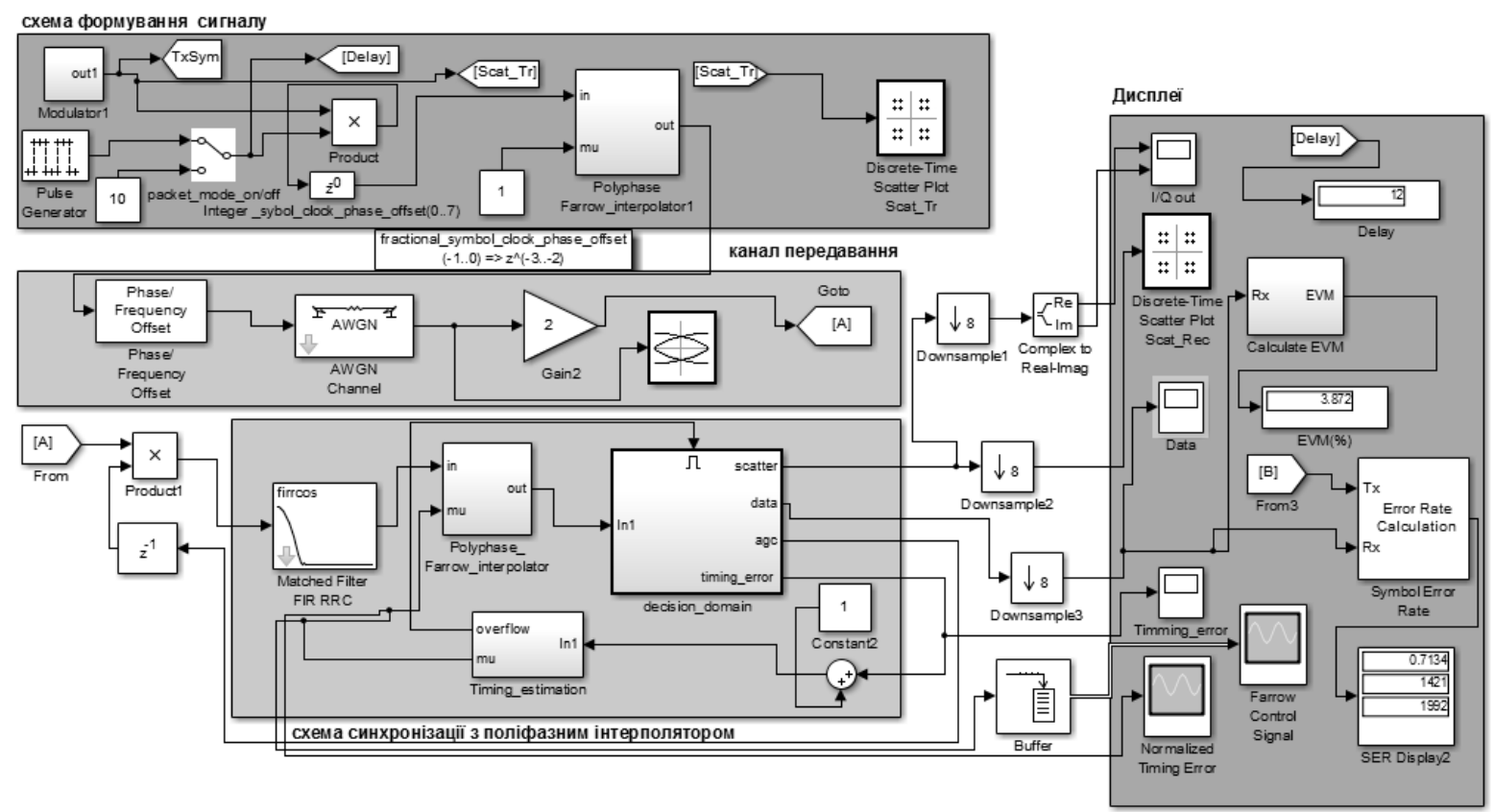

Рис. 9. Імітаційна схема системи передачі даних для дослідження інформаційно-управляючого пристрою синхронізації з поліфазним інтерполятором

«Polyphase_Farrow_interpolator», інформаційно-управляюча підсистема оцінки синхронізації, де відповідно до формули (1) формуються: $n_{l}$-вихідна координата, що визначає $I=I_{2}-I_{1}+1$ відліків сигналу для використання $l$-м інтерполятором; $\mu_{l}$-дробовий інтервал дискретизації який визначає коефіцієнти фільтра $l$-го інтерполянту.

В ході експерименту проводилося вимірювання виграшу в підвищенні завадостійкості обробки сигналів, визначення помилки за констеляційною діаграмою.

Для оцінки динаміки спотворення сигналу в каналі передачі інформації будемо користуватися величиною вектора помилки EVM (Error Vector Magnitude). EVM визначається як відношення середньоквадратичної величини вектора помилки до пікового значення вектора, зафіксованого для реальних символів. Тоді під вектором помилки будемо розуміти відстань між розрахунковим і фактичним положенням символу на констеляційній діаграмі. Ї̈̈ значення визначається за рахунок вимірювання констеляційної діаграми, яка враховуе всі види спотворень. 
Загальна формула для визначення помилки має такий вигляд [9]:

$$
\mathrm{EVM}=\sqrt{\frac{1 / N \sum_{i=1}^{k}\left(e_{k}\right)}{1 / N \sum_{i=1}^{k}\left(I_{k}^{2}+Q_{k}^{2}\right)}} \cdot 100 \% \text {, де: } e_{k}=\left(I_{k}-\overline{I_{k}}\right)^{2}+\left(Q_{k}-\bar{Q}_{k}\right)^{2} \text {. }
$$

\section{Експериментальні дані та їх обробка}

На рис. 10-14 представлені результати дослідження інформаційноуправляючого пристрою блоку синхронізації з багатофазною фільтруючою системою у вигляді дисплея для оцінки часової помилки і дисплея сигналу с узгодженого поліфазного фільтра.

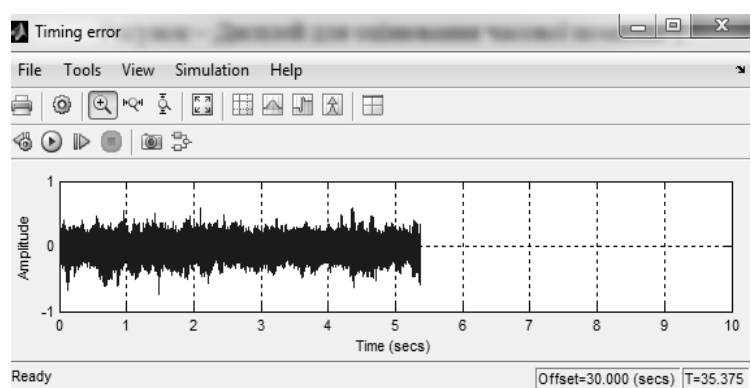

Рис. 10. Дисплей для оцінки часової помилки (детектор часової помилки для рис. 2)

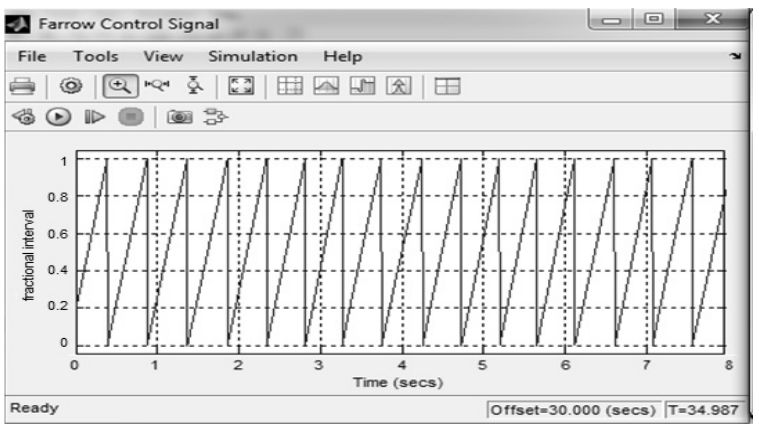

Рис. 12. Дисплей для оцінювання сигналу з інтерполятора Фарроу (результати моделювання: реакція на стрибок фази для тактової синхронізації, цикл працює при 2 відліках/символ, з детектором максимальної правдоподібності і інтерполяційним фільтром Фарpoy $(\mu=1))$

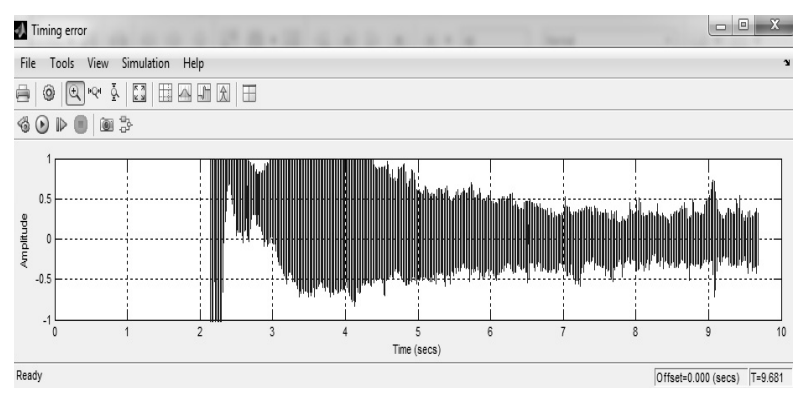

Рис. 11. Дисплей для оцінки часової помилки (детектор часової помилки для рис. 6)

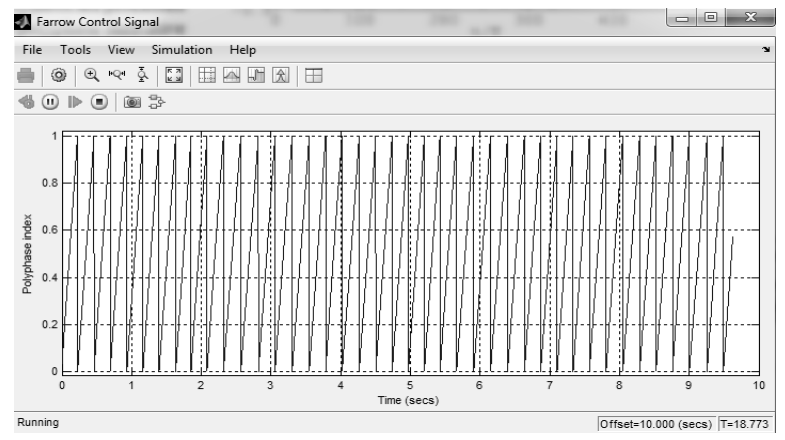

Рис. 13. Дисплей для оцінки сигналу з інтерполятора Фарроу (результати моделювання: реакція на стрибок фази для тактової синхронізації, цикл працює при 2 відліках/символ з детектором максимальної правдоподібності та 32 -х ланковим узгодженим фільтром)

На рис.14 сигнал на виході банку фільтрів в тривимірному поданні. 


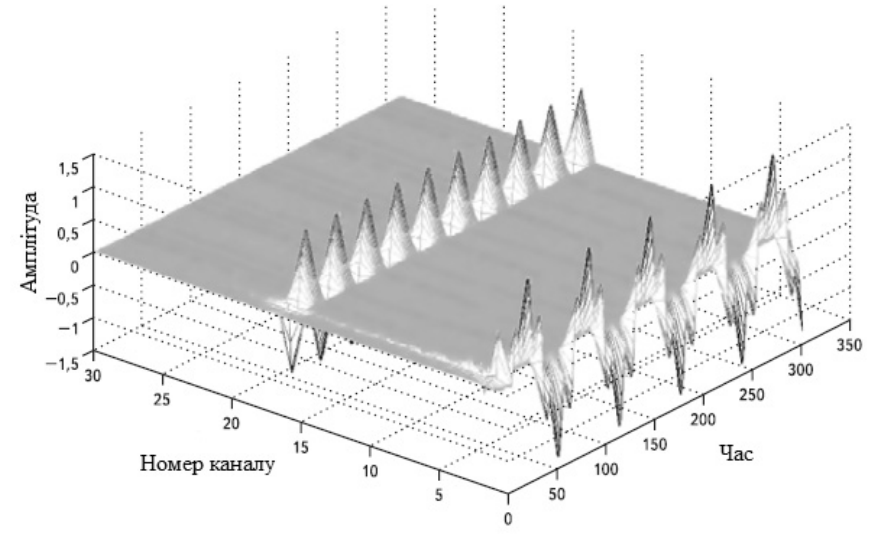

Рис. 14. Сигнал на виході банку фільтрів

На рис. 15 представлені дисплеї для оцінки відстеження динаміки зміни помилки синхронізації, а на рис. 16 квадратурні сигнали $(I / Q)$ в пристрої синхронізації.

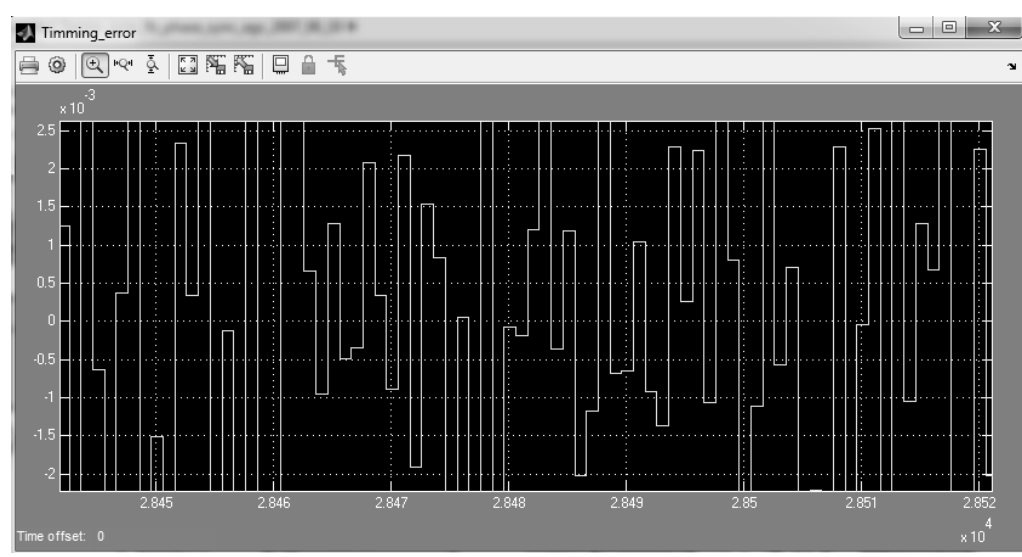

Рис. 15. Дисплей для оцінки відстеження динаміки зміни помилки синхронізації в системі управління

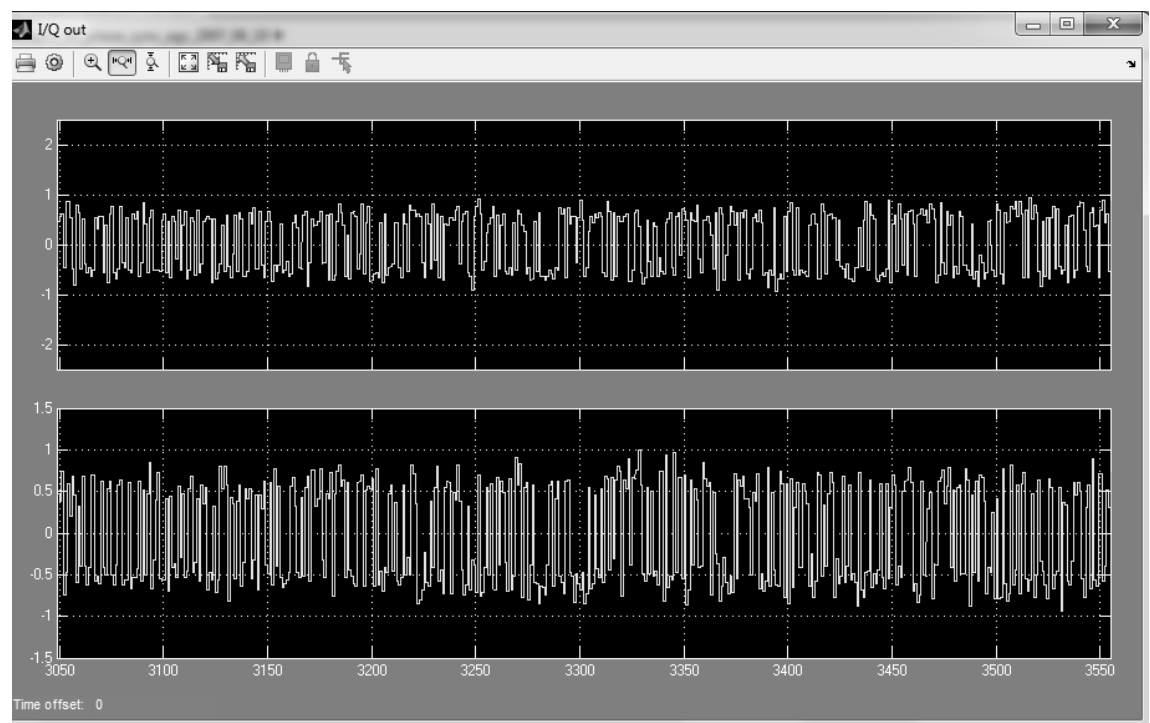

Рис. 16. Дисплей для оцінки відстеження динаміки зміни квадратурних сигналів $(I / Q)$ в пристрої синхронізації 
На рис. 17 і 18 констеляційні діаграми отримані методом імітаційного моделювання, зокрема на рис. 17 - діаграма, отримана після каналу передачі інформації, а на рис. 18 - діаграма відновленого сигналу після системи синхронізації.

На рис. 19 подано констеляційну діаграму, отриману на передавальній стороні каналу передачі інформації у підсистемі «схема формування сигналу». В дослідженнях використана квадратурна фазова маніпуляція QPSK [2]. На рис. 20 представлені констеляційні діаграми для оцінки ефективності застосування систем синхронізації. Спостерігаємо досить якісне відтворення сигналу, що передається.

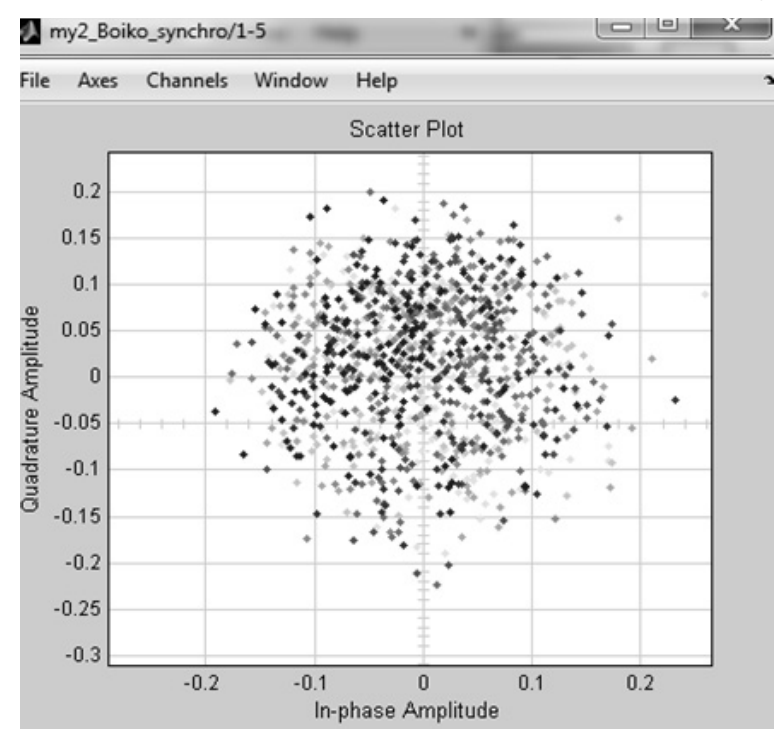

Рис. 17. Констеляційна діаграма сигналу після каналу передачі інформації

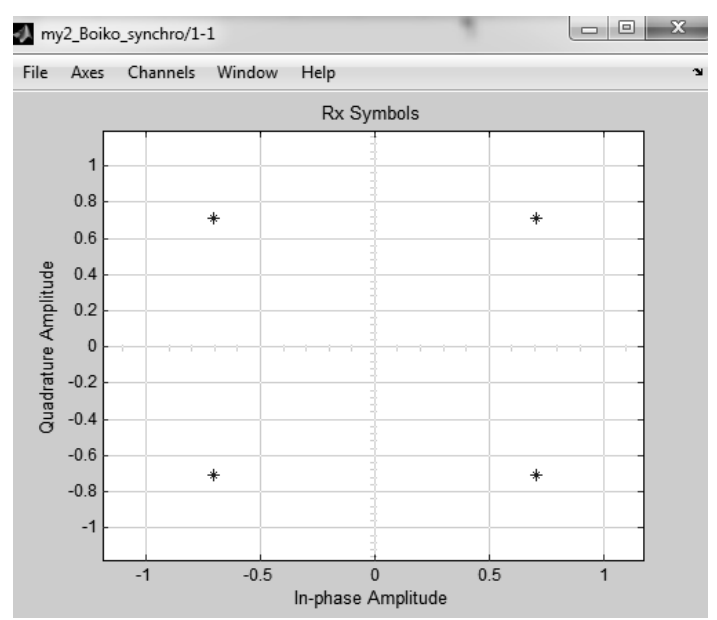

Рис. 19. Констеляційна діаграма на передавальній стороні каналу передачі інформації

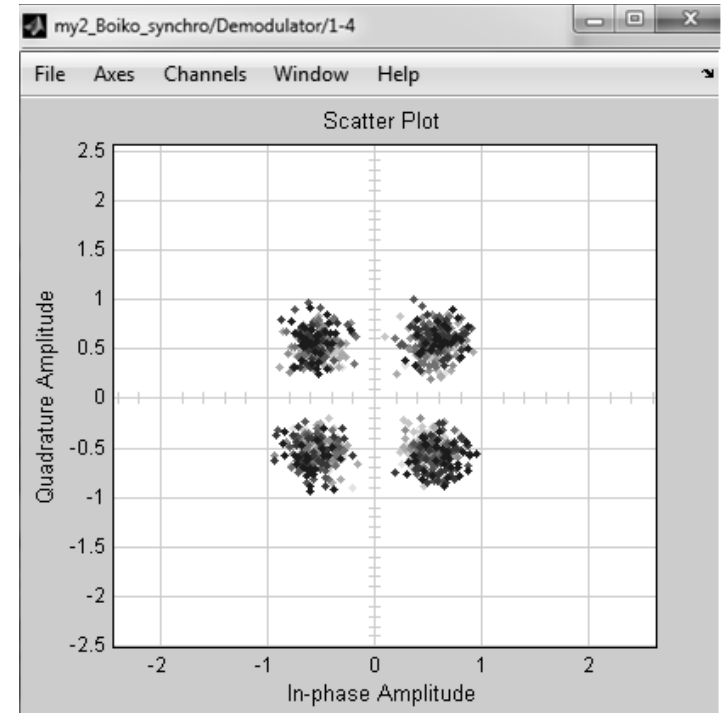

Рис. 18. Констеляційна діаграма відновленого сигналу після системи синхронізації

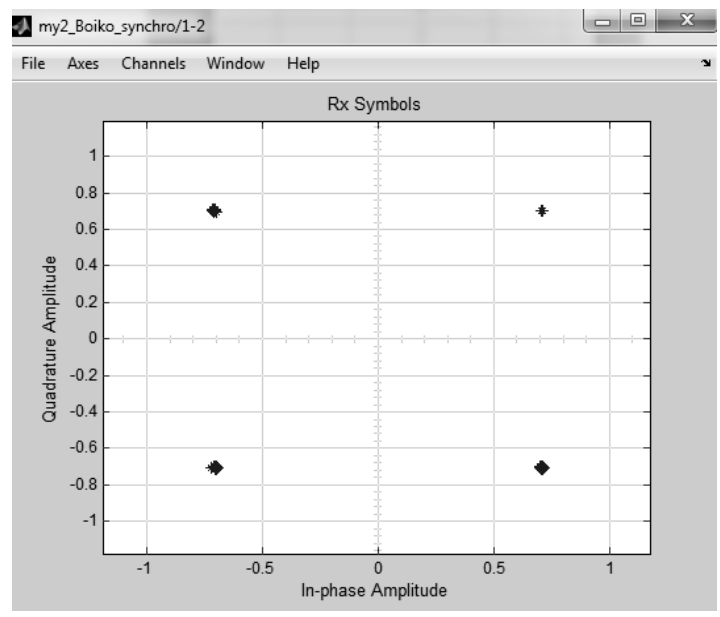

Рис. 20. Констеляційна діаграма відновленого сигналу після спрацьовування систем синхронізації на приймальній стороні 
На рис. 21 представлено констеляційну діаграму отриману методом математичного моделювання на приймальній стороні в системі тактової синхронізації, а на рис. 22 - діаграма, отримана для системи фазової синхронізації.

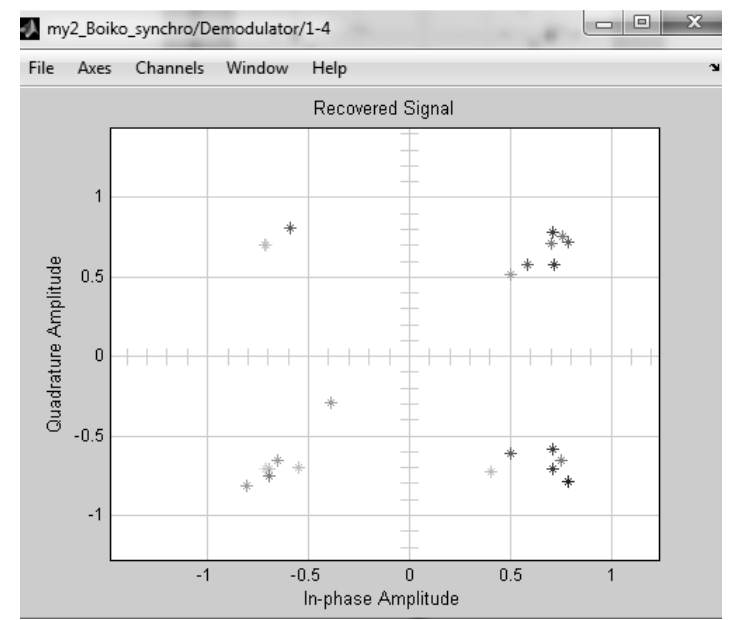

Рис. 21. Констеляційна діаграма на приймальній стороні каналу передачі інформації в системі тактової синхронізації

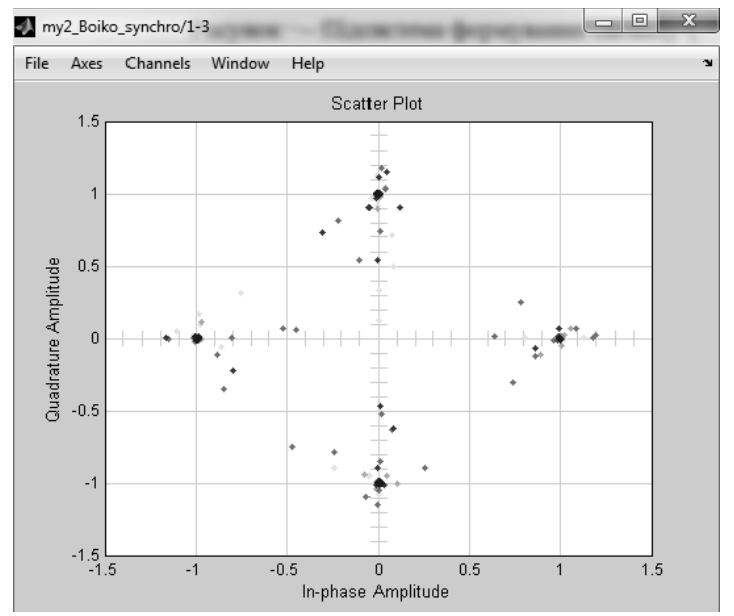

Рис. 22. Констеляційна діаграма на приймальній стороні каналу передачі інформації в системі фазової синхронізації

Зокрема, на рис. 22 досить явно проглядаються наслідки виникнення ефекту "зворотної роботи". В пристрої обробки сигналів констеляційна діаграма класичної QPSK розвертається на $90^{\circ}$, що вимагає застосування способів компенсації зворотної роботи або використання зміщеної (OQPSK) маніпуляції [9].

Як детектор помилки в інформаційно-управляючій системі на рис. 9, вихід «timing error», використаний детектор, імітаційна схема якого представлена на рис. 21. Формалізація процесу роботи такого детектора може бути описана формулами (16-18) [11]:

$$
\begin{gathered}
\xi(n)=U_{I}(n)+U_{Q}(n), \\
U_{I}(n)=\left[Y_{I}\left((n-1) \cdot T+\Psi_{n-1}\right)-Y_{I}\left(n T+\Psi_{n-1}\right)\right] . \\
\cdot Y_{I}\left(n T-T / 2+\Psi_{n-1}\right), \\
U_{Q}(n)=\left[Y_{Q}\left((n-1) \cdot T+\Psi_{n-1}\right)-Y_{Q}\left(n T+\Psi_{n-1}\right)\right] . \\
\cdot Y_{Q}\left(n T-T / 2+\Psi_{n-1}\right) .
\end{gathered}
$$


де $\xi(n)$ - часова помилка в системі синхронізації для $n$-го символу; $Y_{I}$ та $Y_{Q}-$ синфазна і квадратурна складові сигналу; $T$ - період проходження символів; $\Psi_{n}$ - оцінка фази для $n$-го символу.

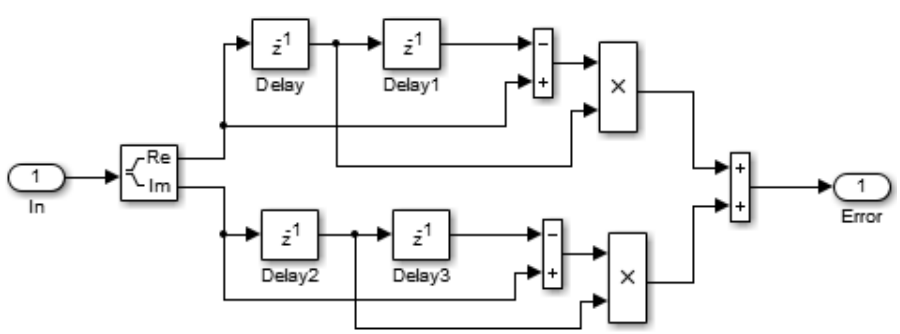

Рис. 21. Підсистема детектора помилки інформаційно-управляючої системи

На рис. 22 представлено око-діаграми отримані методом імітаційного моделювання на передавальній стороні - a, й приймальній стороні - б, каналу передачі інформації. Спостерігаємо задовільний розкрив око-діаграми на рис. 22 б і зменшення джитеру в порівнянні з діаграмою на рис. 22 , а.

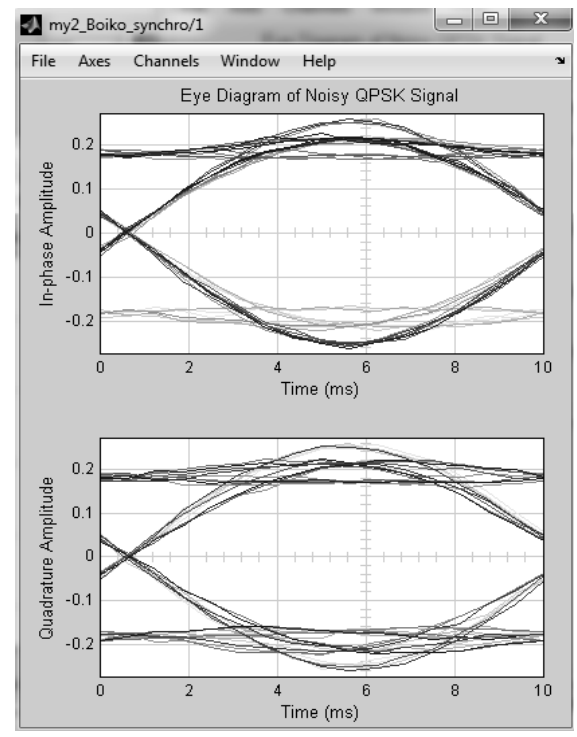

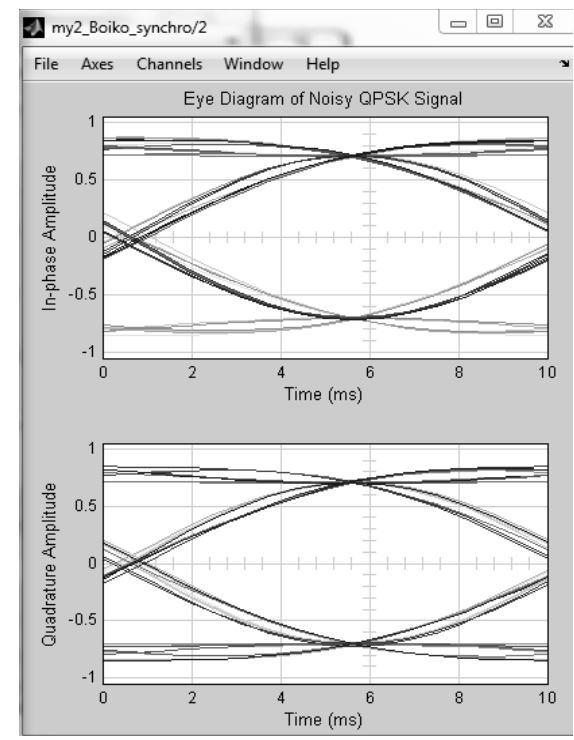

б

Рис. 22. Око-діаграми для оцінювання спотворень сигналів на передавальному - а, й приймальному - б боці каналу передачі інформації

На рис. 23 і 24 результати дослідження схеми керування пристрою синхронізації, отримані методом імітаційного моделювання.

Зокрема, на рис. 23 представлена оцінка фазової помилки в пристрої фазової синхронізації системи управління. Спостерігаємо флуктуаційну картину зміни оціночної кривої навколо середнього значення помилки фази носійної. Використання модифікованої схеми синхронізації дозволяє зменшити флуктуації фази приблизно в 2,02 рази в умовах експерименту. На рис. 24 цифрою 1 -показана фактична затримка, 2 -оцінена затримка для набору з 100 символів в пристрої тактової синхронізації. Результати моделювання показують, що застосування запропонованого методу синхронізації дозволяє здійснити відстеження затримки, оціночна крива змінює 
регулярність і має спотворення в залежності від структури пристрою. Тобто, в цілому експериментальні дослідження вказують на ефективність прийнятих рішень щодо використання модифікованих схем синхронізації.

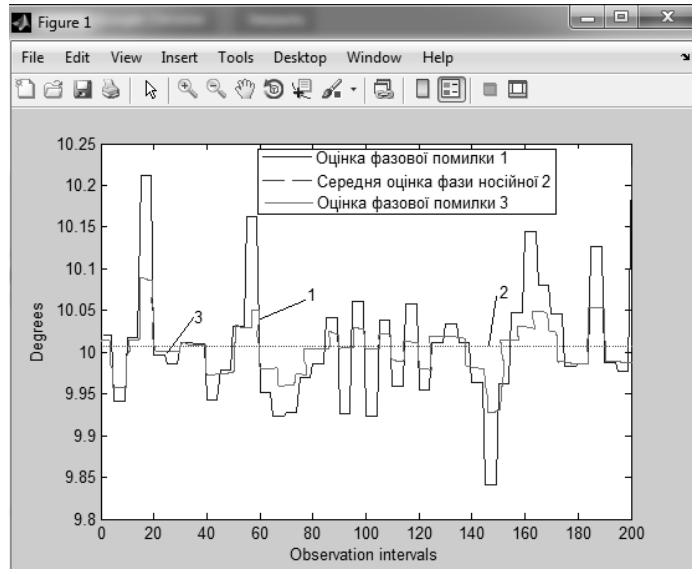

Рис. 23. Дисплей для оцінки фазової помилки в пристрої фазової синхронізації:

1 і 3 - оцінка отримана в результаті моделювання; 2 - середня оцінка фази носійної

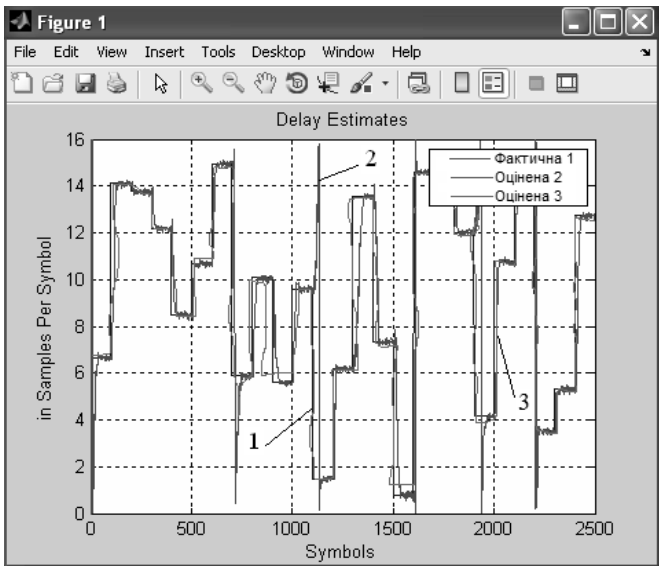

Рис. 24. Дисплей для оцінки затримки символів в пристрої тактової синхронізації: 1 - фактична оцінка; 2 і 3 - оцінка отримана в результаті моделювання

На рис. 25 представлені результати дослідження завадостійкості блоку прийому i обробки сигналів із застосуванням запропонованих рішень по використанню інформаційно-управляючих інтерполяційних схем.

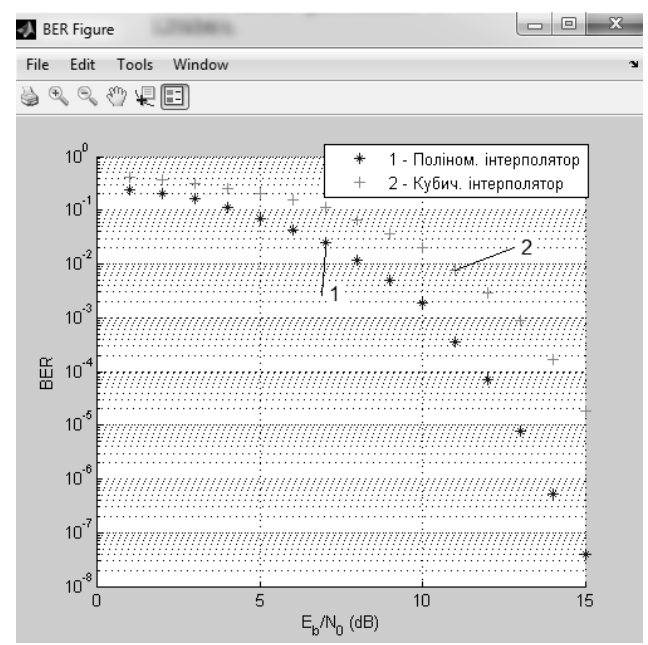

Рис. 25. Залежності для оцінки завадостійкості у вигляді бітової помилки (BER) від відношення $E_{b} / N_{0}$ (сигнал/шум) для блоку обробки сигналів у випадку

QPSK: 1 - поліноміальний (поліфазний інтерполятор, модифікований) 2 - кубічний інтерполятор за структурою Лагранжа

Зокрема, підвищення завадостійкості можна визначити шляхом визначення енергетичного виграшу від застосування поліфазних інтерполятором в системі управління. Порівняння результатів дослідження завадостійкості схем синхронізації, на основі модифікованої структури та кубічного інтерполятора Лагранжа для QPSK, дозволяє встановити, 
що енергетичний виграш для рівня $\mathrm{BER}=10^{-4}$ (ймовірність бітової помилки) становить 2,2 дБ.

\section{Висновки}

Аналіз проведених досліджень дозволяє встановити, що використання запропонованих схем управління і обробки сигналів в системах синхронізації ефективно зменшує помилки відтворення даних в телекомунікаційних каналах. Порівняльна оцінка запропонованих схем по дисплею EVM, дозволила отримати значення помилки по констеляційній діаграмі для випадку використання інтерполяційної конструкції Фарроу на рівні 3\% . Для випадку застосування багатофазної конструкції, результати дослідження яких представлені на рис. 10-13, на рівні 5,5\% . Тобто, в цілому помилка зменшується в 1,8 рази. Крім того, відзначаємо зменшення амплітуди часової помилки, дивитися рис. 10 і рис. 11, в 1,8 рази. Частота проходження контрольного сигналу по дисплею (Farrow Control Signal) в умовах експерименту відрізнялася в 2,5 рази. Однак, отримані результати дозволяють встановити наступне: архітектура пристрою синхронізації на основі банку багатофазних фільтрів має дві переваги в порівнянні з пристроями синхронізації з інтерполяційним пристроєм: подібні пристрої містять у своїй структурі окремий інтерполяційний фільтр, крім узгодженого фільтра (дивитися рис. 2). У випадку багатофазної узгодженої фільтращії, блок управління синхронізацією не вимагає наявність додаткового інтерполяційного пристрою, при цьому знижується складність пристрою синхронізації. Крім того, в разі використання пристрою синхронізації на основі багатофазного банку узгоджених фільтрів можна реалізувати конструкцію для детектора з вікном на «випередження-затримку». В таких схемах виходи багатофазних фільтрів безпосередньо використовуються для формування оцінки фазової помилки.

\section{Список використаних джерел}

1. Boiko, J. M., Eromenko, A. I. (2014). Improvements Encoding Energy Benefit in Protected Telecommunication Data Transmission Channels. Communications. Science Publishing Group, USA. Vol. 2, No. 1. - P. 714. doi: 10.11648/j.com.20140201.12.

2. Juliy Boiko, Victor Stetsiuk, Victor Michan. (2012). Improving noise immunity of QPSK demodulation of signals in digital satellite com- 
munication systems. TCSET'2012 IEEE. 21 - 24 February, pp. 257, Lviv Slavske.

3. J. M. Boiko, A. I. Eromenko. (2014). Solutions Improve Signal Processing In Digital Satellite Communication Channels. 20th International IEEE conference on microwaves, radar and wireless communications. MIKON-2014. June 16-18, pp. 126-129, Gdansk - Poland.

4. Juliy Boiko, Oleksander Eromenko. (2014). Noise immunity assessment in telecommunication systems with cascade encoding structures. TCSET'2014 IEEE. 25-26 February, pp. 431-433, Lviv - Slavske.

5. Boiko, J. M. (2013). Improving effectiveness for processing signals in data transmission channels with phase manipulation. 23rd International IEEE Crimean Conference "Microwave \& Telecommunication Technology" September 9-13, pp. 262-263, Sevastopol.

6. Oleg Shynkaruk, Juliy Boiko, Oleksander Eromenko (2016). Measurements of the energy gain in the modified circuit signal processing unit. TCSET'2016 IEEE. 23-26 February, pp. 582-585, Lviv - Slavske.

7. Boiko, J. M., Eromenko, A. I. (2015). Analysis of solutions to improve efficiency of signal processing devices in telecommunication. European Applied Sciences. Germany. № 5. - P. 47-56. ISSN: 2195-2183.

8. Boiko, J. M., Eromenko, A. I. (2014) Problems synthesis device clock synchronization receivers satellite telecommunication data transmission systems. Visn. NTUU KPI, Ser. Radioteh. radioaparatobuduv., no. 58, pp. 55-66. (in Ukrainian). ISSN: 2310-0397.

9. Boiko, J. M. (2015) Increasing the noise immunity of signal processing units of telecommunications on the basis of the modified synchronization schemes. Visn. NTUU KPI, Ser. Radioteh. radioaparatobuduv., no. 61, pp. 91-107. (in Ukrainian) ISSN: 2310-0397.

10. Boiko, Yu. M., Yeriomenko, O. I., Tkachuk, V. M. (2014). Optimization of receiver synchronization devices of protected telecommunication data transmission systems. Visn. Vinnickogo politechnichnogo institute, Ser. Radioelectronics and equipment radioelectronic., no. 5, pp. 144-151.p. (in Ukrainian). ISSN: 1997-9266.

11. F. M. Gardner (1990). Frequency Detectors for Digital Demodulators via Maximum Likeli-hood Derivation, Final Report: Part II: ESTEC Contract No. 8022/88/NL/DG, Gardner Research Company.

12. I. R. Parhomey, J. M. Boiko, O. I. Eromenko, Features of digital signal processing in the information control systems of multipositional 
radar, Journal of Achievements in Materials and Manufacturing Engineering 77/2 (2016) 75-84.

13. J. Boiko, I. Parhomey, Automated control system radar work, Measurement and control in complex systems, 13th IEEE International Conference, MCCS - 2016, Vinnytsia, 2016, 109-111. 